\title{
PROFIL PROGRAM PENGALAMAN LAPANGAN (PPL) MAHASISWA PROGRAM STUDI PENDIDIKAN SEJARAH PADA SMP DI METRO
}

\author{
Bobi Hidayat, S.Pd., M.Pd. \\ Program Studi Pendidikan Sejarah, FKIP Universitas Muhammadiyah Metro \\ hidayat_bobi@yahoo.com
}

\begin{abstract}
Abstrak
Penelitian ini mengkaji tentang pelaksanaan program pengalaman lapangan (PPL) pada mahasiswa program studi pendidikan sejarah di SMP. Tujuan penelitian ini adalah ingin mendapat gambaran mahasiswa program studi pendidikan sejarah yang melaksanakan PPL di SMP dan dampak yang terjadi pada siswa yang diajarnya. Metode pengumpulan data yang digunakan adalah dokumentasi dan wawancara. Setelah data terkumpul, data akan divalidasi dengan cara triangulasi. Temuan dalam penelitian ini adalah banyak mahasiswa program studi pendidikan sejarah yang mengajar di SMP tidak sesuai dengan bidang keahliannya sehingga mahasiswa mengalami kesulitan dalam menyampaikan materi dan berdampak pada hasil belajar siswa yang diajar kurang optimal.
\end{abstract}

Kata kunci: Program Pengalaman Lapangan, Profesionalisme Guru, Hasil Belajar

\begin{abstract}
This research reviews the implementation of field experience program (PPL), especially for the students of history major who carry out the field experience program (PPL) in junior high school. The research purpose is to get a clear description about the history major students who conducted the program in junior high school and its impact to the students they teach. The data collection methods used were documentation and interviews. After the data have been collected, the data were validated by triangulation. The result of this study shows that many students of history major taught unsuitable lesson so they had difficulties in delivering materials and it caused unperfect learning outcomes of the junior high school students they taught.
\end{abstract}

Keywords: Field Experience Program (PPL), Teacher Profesionalism, Student learning Outcomes

\section{PENDAHULUAN}

Menurut Permendiknas No 16 tahun 2007

tentang profesionalisme guru, guru dituntut memiliki empat kompetensi dasar. Kompetensi itu meliputi pedagogik, kepribadian, profesional, dan sosial. Salah satu kompetensi yang menuntut guru menguasai konsep dibidangnya adalah komptensi profesional. Kompetensi ini mendorong guru untuk menguasai konsep dibidangnya secara mendalam. Selain menguasai konsep dibidangnya, guru yang profesional juga dituntut untuk memberi pembelajaran kepada siswanya sesuai dengan bidang keahliannya secara baik.

Universitas Muhammadiyah Metro merupakan lembaga pendidikan yang ingin menciptakan dan membentuk guru yang profesional sesuai dengan peraturan pemerintah. Salah satu usaha yang dilakukan adalah dengan mengadakan kegiatan Program Pengalaman Lapangan (PPL) bagi mahasiswa calon guru. Program Pengalaman Lapangan (PPL) merupakan suatu kegiatan kurikuler yang dilakukan oleh mahasiswa yang mencakup kegiatan praktik pelaksanaan pembelajaran di kelas 
dan tugas-tugas kependidikan di luar kelas (Tim Penyusun Buku Panduan PPLT, 2013:1). Program ini diintegrasikan dengan kegiatan di masyarakat supaya mahasiswa selain melatih dan mengasah kemampuan mengajarnya, mahasiswa juga dilatih untuk mengembangkan kemampuan kepribadian dan sosialnya. Kegiatan ini diharapkan mampu mendorong dan membantu mahasiswa menjadi calon guru yang profesional.

\section{Program Pengalaman Lapangan} (PPL) melibatkan beberapa sekolah dan jenjang pendidikan. Sekolah yang digunakan untuk pelaksanaan Program Pengalaman Lapangan (PPL) antara lain Sekolah Menengah Pertama (SMP), Sekolah Menengah Atas (SMA) dan Sekolah Menengah Kejuruan (SMK). Penempatan mahasiswa dilakukan dengan mengkombinasikan beberapa mahasiswa dari beberapa program studi ke dalam satu sekolah. Hal ini dilakukan karena sudah disesuaikan dengan kondisi guru di sekolah yang bervariasi.

Berdasarkan beberapa sekolah yang menjadi rujukan penempatan mahasiswa untuk melakukan kegiatan Program Pengalaman Lapangan (PPL), terdapat beberapa mahasiswa Program Studi Pendidikan Sejarah yang ditempatkan di Sekolah Menengah Pertama (SMP). Hal ini menjadi penting untuk dicermati, karena kemampuan mahasiswa Program Studi Pendidikan Sejarah mengajar tidak sepenuhnya sesuai dengan kurikulum yang diterapkan di sekolah yaitu IImu
Pengetahuan Sosial (IPS) terpadu dimana yang menjadi materi pembelajaran berasal dari perpaduan konsep sejarah, ekonomi, sosiologi dan geografi. IPS di sekolah menengah merupakan penyederhanaan atau adaptasi dari disiplin ilmu-ilmu sosial dan humaniora, serta kegiatan dasar manusia yang diorganisasikan dan disajikan secara ilmiah dan pedagogis/psikologis untuk tujuan pendidikan (Somantri, 2001:92). Sehingga IPS di sekolah menuntut guru untuk mampu menguasai semua konsep IPS. Namun kenyataannya Universitas Muhammadiyah Metro belum mampu mencetak guru yang menguasai konsep IPS secara menyeluruh, sehingga dalam pelaksanaan Program Pengalaman Lapangan (PPL), masih menempatkan mahasiswa sesuai dengan program studi yang dimiliki.

Berdasarkan permasalahan di atas, maka permasalahan dalam kajian ini adalah profil keterlaksanaan mahasiswa Program Studi Pendidikan Sejarah dalam mengikuti kegiatan Program Pengalaman Lapangan (PPL), khususnya yang praktik PPL di Sekolah Menengah Pertama (SMP) Kota Metro.

\section{METODE PENELITIAN}

Penelitian ini dilaksanakan melalui metode pengumpul data dengan cara dokumentasi, dimana penelitian ini akan mengungkap hasil dan fakta yang berasal dari laporan praktik lapangan mahasiswa. Dokumen yang akan diungkap dan dibedah 
adalah laporan Program Pengalaman Lapangan yang telah dibuat oleh mahasiswa setelah selesai mengikuti kegiatan Program Pengalaman Lapangan, terutama laporan mahasiswa yang mengikuti Program Pengalaman Lapangan di SMP. Dokumen yang dijadikan sumber penelitian adalah dokumen primer dan sekunder yang menunjang penelitian. Selain dokumentasi, peneliti juga menggunakan metode wawancara. Wawancara yang akan dilakukan adalah wawancara langsung dengan sumber data, yaitu dengan mahasiswa yang mengikuti Program Pengalaman Lapangan (PPL) dan Dosen Pembimbing Lapangan yang membimbingnya.

Setelah data diperoleh, data akan dideskripsikan dan dianalisis, kemudian akan divalidasi menggunakan teknik triangulasi. Dengan teknik ini diharapkan data akan lebih valid dan dapat menggambarkan kondisi yang sebenarnya. Karena triangulasi merupakan salah satu cara untuk mencocokkan data dari berbagai sudut pandang dalam penelitian. Dalam penelitian ini data akan dicocokkan antara data pada laporan Program Pengalaman Lapangan mahasiswa, data wawancara dengan mahasiswa yang mengikuti Program Pengalaman Lapangan, dan data wawancara dengan Dosen Pembimbing Lapangan (DPL).

\section{HASIL DAN PEMBAHASAN}

Berdasarkan hasil laporan Program Pengalaman Lapangan mahasiswa, dapat diketahui bahwa selama mahasiswa Program Studi Pendidikan Sejarah mengikuti PPL di SMP terdapat sebanyak 23 mahasiswa yang tersebar kedalam 12 Sekolah Menengah Pertama (SMP). Setiap sekolah mendapat antara 1-3 mahasiswa Program Studi Pendidikan Sejarah. Selama mahasiswa Program Studi Pendidikan Sejarah mengikuti Program Pengalaman Lapangan di SMP bidang keahlian yang diajarnya sangat bervariasi. Hal itu dapat terjadi dikarenakan mata pelajaran yang terdapat di Sekolah Menengah Pertama merupakan mata pelajaran terpadu yang memadukan empat bidang ilmu yaitu sejarah, geografi, sosiologi dan ekonomi. Hal ini menuntut mahasiswa yang berasal dari Program Studi Pendidikan Sejarah untuk mempelajari bidang ilmu di luar keahlianya supaya dalam menyampaikan materi diluar bidang keilmuanya tidak mengalami hambatan. Untuk lebih jelasnya tentang mata pelajaran yang diampu mahasiswa ketika mengajar di SMP dapat dilihat pada tabel berikut ini:

Tabel 1: Distribusi bidang studi yang diajarkan oleh mahasiswa Program Studi Pendidikan Sejarah di SMP Kota Metro

\begin{tabular}{c|c|c|c}
\hline No & Bidang Studi yang Diajarkan & Jumlah Mahasiswa & Persentase (\%) \\
\hline 1 & Sejarah & $3 \mathrm{Mhs}$ & 13,04 \\
\hline 2 & Geografi & $5 \mathrm{Mhs}$ & 21,74 \\
\hline 3 & IPS & $3 \mathrm{Mhs}$ & 13,04 \\
\hline 4 & Sejarah dan Geografi & $7 \mathrm{Mhs}$ & 30,43 \\
\hline
\end{tabular}




\begin{tabular}{c|c|c|c}
\hline 5 & Sejarah, dan Sosiologi & 1 Mhs & 4,35 \\
\hline 6 & Sejarah, Geografi, dan Sosiologi & 2 Mhs & 8,70 \\
\hline 7 & Sejarah, Geografi, dan Ekonomi & 2 Mhs & 8,70 \\
\hline \multicolumn{2}{r|}{ Jumlah Total } & 23 Mhs & 100 \\
\hline
\end{tabular}

Sumber : Laporan Program Pengalaman Lapangan Mahasiswa Prodi Pend. Sejarah di SMP Kota Metro

Berdasarkan hasil penelitian yang telah dilakukan selama mahasiswa melaksanakan Program Pengalaman Lapangan, diketahui banyak mahasiswa Program Studi Pendidikan Sejarah tidak mengajar sesuai dengan bidang keahlianya. Hanya sejumlah 3 mahasiswa atau $13,04 \%$ yang mengajar murni sesuai dengan bidang keahliannya yaitu bidang studi sejarah. Sebanyak 5 mahasiswa atau $21,74 \%$ mengajar bidang studi geografi, dan sebanyak 15 mahasiswa atau 65,22\% harus mengajar sejarah dan bidang studi IPS lainnya.

Temuan ini dapat menggambarkan ketidaksesuaian antara bidang keahlian mahasiswa Program Studi Pendidikan Sejarah dengan bidang keahlian ketika mengajar di sekolah pada saat mahasiswa mengikuti Program Pengalaman Lapangan. Sehingga perlu dikaji ulang tentang cara penempatan mahasiswa Program Studi Pendidikan Sejarah saat akan mengikuti program pengalaman mahasiswa agar terjadi kesesuaian antara bidang keahliannya dengan bidang keahlian ketika mahasiswa mengikuti kegiatan Program Pengalaman Lapangan selanjutnya.

Tujuan dari Program Pengalaman Lapangan adalah melatih mahasiswa calon guru agar mendapat pengalaman mengajar langsung di lapangan. Pengalaman yang diperoleh merupakan pengalaman dari hasil belajar di universitas yang merupakan kumpulan konsep dan teori. Kesesuaian konsep yang dipelajari dengan materi yang diajarkan ketika mengikuti kegiatan PPL menjadi penting untuk diperhatikan.

Selain mahasiswa mengajar diluar bidang studi yang menjadi bidang keahliannya yang berdampak pada kesulitan mahasiswa dalam mengajar, hal lain yang muncul adalah pada hasil belajar siswa yang diajar. Hasil belajar siswa yang diajar mahasiswa tersebut kurang mendapatkan hasil belajar yang optimal, hal ini disebabkan karena mahasiswa yang mengajar harus memberi materi diluar materi sejarah. Mahasiswa dituntut untuk belajar kembali saat akan mengajar, sehingga profesionalisme dalam mengajar belum dapat terwujud sepenuhnya.

\section{PENUTUP}

\section{Simpulan}

Berdasarkan hasil penelitian terungkap bahwa dari sejumlah mahasiswa Program Studi Pendidikan Sejarah yang praktik lapangan di SMP, bidang studi yang diajarnya sangat bervariasi. Hanya sebanyak 3 orang mahasiswa atau 13,04\% yang mengajar sesuai dengan bidangnya yaitu bidang studi sejarah. Mahasiswa yang mengajar bidang studi geografi 5 mahasiswa atau $21,74 \%$, dan yang 15 
mahasiswa atau $65,22 \%$ tidak hanya mengajar bidang studi sejarah, namun mengajar materi IPS lainya yang menuntut keahlian dibidangnya. Hal ini berdampak juga pada mahasiswa karena mahasiswa mengalami kesulitan dalam mengajar diluar materi sejarah dan berdampak pula pada hasil belajar siswa.

\section{Saran}

Berdasarkan hasil penelitian, maka peneliti memberikan saran antara lain:

- Penempatan mahasiswa khususnya mahasiswa Program Studi Pendidikan Sejarah pada Program Pengalaman Lapangan diharapkan tidak menggunakan Sekolah Menengah Pertama (SMP), dikarenakan kurikulum yang berlaku tidak sepenuhnya sesuai dengan keahlian mahasiswa.

- Program Studi Pendidikan Sejarah dalam menyusun kurikulum perkuliahan diharapkan tidak hanya fokus pada materi sejarah, namun diharapkan memberikan materi tentang ke-IPS-an agar mahasiswa memiliki kemampuan dan tidak mengalami permasalahan konsep ketika mengajar di SMP karena kurikulum di SMP khususnya pada mata pelajaran IPS mencakup IPS terpadu.

\section{DAFTAR PUSTAKA}

Somantri, Muhammad Numan. 2001. Menggagas Pembaharuan Pendidikan IPS. Bandung. PPs-UPI dan FPIPS-UPI.
Tim Penyusun. 2013. Buku Panduan PPLT UM Metro. Metro. UPT PPLT UM Metro. 
Profil Program Pengalaman Lapangan (PPL)..., Bobi Hidayat, 61-66 